\title{
LA DisPuta POR El TEMPlo DE Copoya Conflicto religioso en Tuxtla Gutiérrez, Chiapas
}

Omar López Espinoza

Pero aunque el momento sea crítico por no dejarnos bajar a las auténticas Madres Santísimas, no se acabará nuestra fe, nuestro amor por la Madre Santísima...

Don Gustavo, devoto de las Vírgenes de Copoya

\section{La disputa por las imágenes}

Como vienen haciendo desde hace mucho tiempo, a principios de 2004 los habitantes de Tuxtla Gutiérrez - capital del estado de Chiapas_y zona conurbada, se organizaron para celebrar a las Vírgenes de Copoya. ${ }^{1}$

La fiesta se celebra dos veces al año: del 30 de enero a, poco más o menos, final del mes de marzo; y del 14 al 23 de octubre. En estas dos ocasiones tres imágenes son llevadas a la ciudad de Tuxtla Gutiérrez. Las "Copoyitas" son símbolos que poseen gran veneración, no sólo entre la gente que se identifica como de "el Costumbre", sino de muchos devotos que no participan de las actividades religiosas que realizan la Mayordomía del Rosario y la Junta de Festejos de Copoya: aun así se sienten muy unidos a ellas.

Lo anterior puede verse en las Bajadas y Subidas, ${ }^{2}$ dos momentos rituales que convocan a un número importante de personas. De su celebración se hacen cargo la Mayordomía del Rosario y la Junta de Festejos de Copoya, además estas asociaciones también conmemoran otras celebraciones religiosas, como la Inmaculada Concepción, la Semana Santa, la Santa

Omar López Espinoza, estudiante de maestría en Ciencias Sociales con opción en Estudios Fronterizos, CESMECA-UNICACH.
Cruz, el Corpus Christi, la Octava de Corpus, la Sagrada Familia de las Chabelitas y San Roque.

Las Vírgenes de Copoya son custodiadas desde hace muchos años en la iglesia del poblado rural de Copoya, ahora unido a Tuxtla Gutiérrez. El templo fue construido por la población misma, usando los terrenos del común.

La fiesta consiste en una peregrinación que durante varias semanas recorre diferentes zonas de la ciudad y termina con el regreso de las imágenes a su templo. Pero en 2004 las Vírgenes no volvieron a su casa.

Los primeros indicios de desestabilización sociorreligiosa se presentaron a finales del año 2003, a raíz de que el sacerdote de Copoya — Severo Castellanos-, ordenara a un grupo de jóvenes derribar algunos árboles que se encontraban en el patio contiguo al templo porque impedían la construcción de una casa destinada al sacerdote. Este suceso provocó el descontento de los costumbristas debido a que no se tomó en cuenta la opinión de la Junta de Festejos de Copoya ni de la Mayordomía del Rosario. En meses posteriores, el nuevo párroco de Copoya pidió junto al entonces obispo de la diócesis de Tuxtla, Chávez Botello, que la Mayordomía y la Junta cambiaran la fecha de los 
festejos de las Vírgenes de Copoya; petición que fue negada por los costumbristas. El 26 de marzo de 2004 los representantes de las asociaciones religiosas zoques realizaron una conferencia de prensa en donde fijaron su postura respecto a este conflicto:

[La Mayordomía y la Junta] no reconocen la autoridad de la Iglesia para la modificación de las tradiciones, [Además] la Iglesia no es nadie para decirle que es lo bueno y que es lo malo, los curas no pueden evaluar lo relativo a los festejos, porque no conocen lo que significa para sus familias el Costumbre; si quiere quitarnos a las Vírgenes correrá sangre.

El día 28 de marzo de 2004, durante la procesión que se organiza para el regreso de las Vírgenes de Copoya a su templo, se presentaron los primeros roces entre grupos: prodiocesanos ${ }^{3}$ y costumbristas. ${ }^{4}$

La procesión partió a las 8 de la mañana de la casa del segundo Mayordomo de la Virgen de Candelaria. ${ }^{5}$ Este día el contingente de feligreses que transportaba las imágenes planeó hacer el recorrido por Tuxtla Gutiérrez, tomando una de las principales arterias de la ciudad, el bulevar Ángel Albino Corzo; continuaron por la Avenida Central hasta llegar a la catedral de San Marcos. Una vez aquí, las imágenes fueron colocadas frente al atrio de la Catedral durante unos minutos, posteriormente la procesión siguió su recorrido hacia Copoya. Más tarde, un par de kilómetros antes de llegar al santuario del mismo nombre, el grupo de costumbristas fue interceptado por aproximadamente 300 jóvenes de diferentes parroquias. Este grupo de prodiocesanos gritaba consignas en favor del párroco, el obispo y el papa; se identificaban porque llevaban una cinta colocada sobre la frente, tenía como signo particular una cruz al centro; otros más portaban globos de colores blanco y amarillo.

La procesión llegó hasta una cuadra antes de llegar a la parroquia, pues los costumbristas consideraron que la intención del otro grupo era que una vez que fueran depositadas las imágenes en el templo, se perdiera su resguardo; por lo que decidieron dirigirse a la casa del presidente de la Junta de Festejos - José Paredes Jiménez- para protegerlas en este lugar. La decisión tomada por los Albaceas, Priostes, Mayordomos y Socios desató el enojo entre los prodiocesanos y se presentaron los primeros brotes de violencia sin llegar a la agresión física. Las discusiones entre los grupos no pasaron de los insultos:

Qué tienen que venir a mandar la gente de Tuxtla a Copoya, el presidente es un roba santos, que la gente de Tuxtla haga su fiesta allá en la ciudad y no aquí en Copoya, esos de la Junta quiere que se les eche bala.

Después del día 28 de marzo de 2004 las imágenes comenzaron a ser custodiadas por miembros de la Junta de Festejos y la Mayordomía en la casa del presidente de la Junta de Copoya: temían ser despojados de las Vírgenes. Hubo rumores de que un grupo de personas influido por el nuevo párroco y el obispo tenía la intención de arrebatar las imágenes y el templo a esta agrupación. ${ }^{6}$ La duda se prolongó hasta el 27 de abril de 2004, cuando la Junta guardaba las imágenes en la casa del presidente. ${ }^{7}$

Durante toda la mañana de este día, los habitantes de Copoya vieron movilizarse a varios grupos de personas que llegaban al pueblo y se retiraban; otros más se iban concentrando cerca del templo. La dinámica se mantuvo hasta aproximadamente las 19:00 horas, momento en que un grupo identificado como prodiocesanos convocó a una misa, la cual se llevaría a cabo en el templo de las "Copoyitas". Terminado el servicio religioso un primer contingente de éstos se dirigió a la casa del presidente de la Junta de Festejos, algunos miembros entraron por la fuerza a la vivienda de don José Paredes, mientras que otros permanecían en el exterior de la casa para asegurarse que los costumbristas no pudieran asistir a sus compañeros. 
La intención era ejercer presión en contra de la Mayordomía y la Junta de Festejos para que regresaran a las tres imágenes al lugar que les correspondía, el altar principal del templo de Copoya. Al mismo tiempo, otro grupo se concentraba en el atrio del templo y en la plaza central del pueblo. ${ }^{8}$

Algunos prodiocesanos tenían como objetivo impedir que los costumbristas accedieran a la casa del presidente, y que entrara en el pueblo la fuerza pública. De hecho la policía llegó, pero varios prodiocesanos amenazaban con agredir al cuerpo de antimotines si intervenían, por lo que permanecieron a la entrada de la población sin poder hacer nada.

Aproximadamente a las 8:00 de la noche la agitación continuaba, los ánimos en los prodiocesanos se encontraban al máximo. Cuando llegó al lugar el Albacea de la Mayordomía del Rosario, don Paulino Jonapá, fue recibido por un grupo de personas que entre jalones y forcejeos trataban de llevarlo - junto con un Ramilletero- ${ }^{10}$ a la plaza central. Amenazaban con desnudarlos y amarrarlos a un árbol mientras no se solucionara el problema. Incluso en caso de que la Mayordomía y la Junta de Festejos no devolvieran las imágenes al templo, este grupo amenazó con quemar a los dos retenidos.

Al ver así la situación el Albacea tomó la decisión de entregar las imágenes. Para ello pidió a una persona de su confianza que fuera a decir a los principales retenidos en la casa del presidente de la Junta de Festejos de Copoya que llevaran a las Vírgenes al Templo. Haciendo caso de la orden dada por el Albacea, alrededor de las 11:00 o 12:00 de la noche algunos Priostes y Mayordomos, mediante procesión, devolvieron las imágenes a su santuario. Al término de ésta se hizo firmar un documento a los principales costumbristas. Finalmente, el grupo de prodiocesanos liberó a los retenidos y se marcharon de la población.

Las diferencias entre la Iglesia y las asociaciones religiosas populares en Tuxtla no son un fenómeno nuevo. Se sabe que durante todo el siglo XX se han presentado conflictos entre la Iglesia y las agrupaciones "católicas populares" conformadas por laicos, principalmente zoques. Por ejemplo, el actual templo del Niño de Atocha es un recinto que en sus inicios fue ermita administrada por una Junta de Festejos. Esta asociación se encargaba de organizar las celebraciones anuales al santo; sin embargo, la Iglesia intervino en sus festejos y despojó del control de las fiestas y del templo a la organización por considerar que algunas prácticas rituales rayaban en los excesos, como los gastos en comida, música, cohetes y alcohol. ${ }^{11}$ Por otra parte, a lo largo del siglo XX la Iglesia poco a poco fue ganando terreno, sus redes se extendieron por varias partes de la ciudad, llegaron a apropiarse de varias ermitas de barrio, las cuales fueron convertidas en templos. Ejemplo actual de ello son las iglesias del Señor de las Ampollas, el Señor con Diente, Guadalupe, entre otras. Espacios que originalmente eran controlados y administrados por los vecinos del lugar, lejos de la supervisión eclesiástica.

Este ejemplo es parte de una larga historia de conflictos entre la administración eclesiástica del culto y el "catolicismo popular" en Tuxtla. Con las Vírgenes de Copoya, sin embargo, hay otros elementos que se agregan a la disputa histórica por el control de la celebración, tienen que ver con el proyecto diocesano que hoy por hoy la Iglesia católica lleva a cabo en Tuxtla.

\section{La intervención de la iglesia católica en el "catolicismo popular" de Tuxtla}

La oposición a las formas en que se practica la religión católica por parte de los miembros de las asociaciones zoques en Tuxtla han generado, en los últimos años, un clima de inestabilidad en las históricamente viciadas relaciones entre la Mayordomía del Rosario, la Junta de Festejos de Copoya, y el clero secular de Tuxtla Gutiérrez. ${ }^{12}$ Esto sucede sobre todo en lo que se refiere 
a la llamada "Bajada de las Vírgenes de Copoya".

Durante los primeros meses de 2004 el problema se acentuó debido a las acciones que la diócesis de Tuxtla ha implementado con el afán de "ubicar" la devoción a las Vírgenes de Copoya. De hecho, la Iglesia ha determinado algunas acciones de evangelización para lograr su fin.

\section{Fundación de la parroquia de Copoya}

En este contexto, el anterior representante de la diócesis de Tuxtla, monseñor Chávez Botello, impuso — sin aprobación de los miembros de la Mayordomía y la Junta de Festejos de la localidad de Copoya - el 2 de febrero de 2004 que el templo de esta población se erigiera como parroquia, asignando un sacerdote para su administración permanente. Este hecho fue interpretado por los costumbristas como una muestra de intervención directa por parte de la Iglesia en contra de la Mayordomía del Rosario y la Junta de Festejos, ya que la medida afectaba a la autonomía y los usos y costumbres del grupo. $\mathrm{Y}$ es que durante muchas generaciones, argumentan los costumbristas, las asociaciones "católicas populares" en Tuxtla Gutiérrez se habían caracterizado por defender celosamente sus cultos religiosos, hasta el límite de mantener sus manifestaciones alejadas del dogma católico y de la intervención de los sacerdotes seculares. Consideran que esta intervención busca controlar los aspectos ideológicos y económicos arguyendo la enseñanza de la correcta fe y devoción como meros pretextos. ${ }^{13}$

Los costumbristas radicados en Copoya han observado que su párroco, José Severo Castellanos Valencia, ha asumido una actitud hostil ante las tradiciones zoques debido al desconocimiento que éste tiene de ellas. El párroco de Copoya ha empleado técnicas de evangelización que se contraponen a las concepciones religiosas de la feligresía popular. Por ejemplo, en una misa celebrada en el santuario de las
Copoyitas, ante los asistentes al servicio dominical, el padre Severo quebró una imagen de un Niño Dios — sin bendecir-, con la intención de que los feligreses encauzaran su devoción hacia el Santísimo Sacramento, el Cristo vivo, es decir, el Cristo Sacramentado, y no a otras imágenes. Esta forma de actuar del sacerdote hace pensar a los costumbristas que tiene una inclinación hacia al protestantismo que deviene del puritanismo, ya que dicho grupo religioso no acepta en sus templos reproducciones de imágenes —Cristo, Vírgenes, la Cruz, Santos - ni la veneración de las mismas. Sin embargo, el método empleado por el párroco se realiza, en algunas ocasiones, al final de los retiros espirituales y de crecimiento que organiza la Iglesia a través de sus parroquias en la ciudad de Tuxtla: para la Pastoral Juvenil, los grupos matrimoniales, las pláticas prematrimoniales, las pláticas prebautismales, entre otros. Por otra parte, hace aproximadamente diez años se pedía a los asistentes de estas reuniones que renunciaran a las Vírgenes de Copoya. ${ }^{14}$

\section{Modificación del algunos momentos rituales}

Otro aspecto de esta nueva evangelización es la postura que la Iglesia tiene de modificar algunos momentos rituales del ciclo festivo anual de los zoques, con el objetivo de que la fiesta de las Vírgenes de Copoya se acote al calendario oficial católico. Además, consideran que esta celebración se llevaba a cabo anteriormente en fecha distinta a la que actualmente, 30 de enero, se realiza la "Bajada de las Copoyitas".

En oficio Circular 1/04, con fecha 5 de enero de 2004, la diócesis de Tuxtla Gutiérrez, afirma que:

[...] Las imágenes de la Santísima Virgen María visitarán gradualmente los templos, las parroquias de la ciudad para que su visita sea más sentida y más personas puedan rendirle homenaje; [además de que] a partir 
del próximo año 2005 las imágenes de Ntra. Señora bajarán el 3 de febrero para que las fiestas patronales de Ntra. Sra. de la Candelaria se celebren en su parroquia de Copoya con la presencia de las imágenes [...] (Diócesis Tuxtla, 2004:s/p).

Con esta acción se busca que en años subsecuentes la "Bajada de las Vírgenes de Copoya" cambie de fecha y comience a realizarse a partir del día siguiente a su festejo, ya que la Iglesia considera que la Virgen de la Candelaria debe de pasar su día en su santuario y no fuera de éste. Sin embargo, existe otra imagen de la misma Virgen que desde hace varios años ocupa el lugar de la imagen que se lleva en procesión, la cual es celebrada el 3 de febrero por parte de los miembros de la comunidad católica de Copoya.

\section{Eliminación de algunas prácticas costumbristas}

Otro aspecto que la iglesia busca modificar tiene que ver con la eliminación de algunas prácticas que llevan a cabo los costumbristas dentro de las ceremonias, mismas que la Iglesia considera no gratas. Un ejemplo es el excesivo gasto económico empleado en los alimentos, el licor, los cohetes y la música, especialmente aquella que ameniza los bailes populares que engalanan la fiesta de las Vírgenes, ya sea organizada por los Priostes y Mayordomos o por los Procuradores - pedidoren "Las Pedidas". ${ }^{15}$ En lo que respecta a bailes populares, consumo de alcohol y gastos en exceso, la Iglesia considera que son elementos que en nada dignifican el culto a la Virgen María, sino que por el contrario, desvían y distorsionan la devoción, haciendo olvidar en los participantes que el motivo central de tales festejos es la veneración de la "Madre Santísima".

Los tres elementos anteriores han generado serias pugnas. En primer lugar, entre ambas agrupaciones religiosas: la diócesis por un lado, y la Mayordomía y la
Junta de Festejos por otro. Pero también el conflicto se ha extendido hacia los citadinos tuxtlecos, especialmente entre algunos habitantes de la localidad de Copoya, llegando a presentarse conflictos intracomunitarios entre prodiocesanos - principalmente jóvenes de los grupos de pastoral juvenil, llamados también "encuentristas" - y costumbristas - miembros de la Mayordomía del Rosario y socios de la Junta de Festejos de Copoya.

En términos generales, el proyecto diocesano impuesto por la Iglesia hacia las manifestaciones religiosas zoques es visto por los costumbristas como un acto de despojo en contra de algunos símbolos y significados de los ritos heredados en torno a las Vírgenes de Copoya y sus prácticas festivas, situación que se percibe como un acto que condiciona sus costumbres e impide la libertad de culto, además de ofender sus derechos.

\section{Las raíces del actual proyecto diocesano}

Con un discurso reconociendo esta celebración como una expresión religiosa que alimenta la fe de un sector importante de la población y conserva las buenas tradiciones católicas, la diócesis de Tuxtla ha decidido fortalecer la devoción y asegurar el acompañamiento pastoral con los sacerdotes, disposición que ha sido rechazada abiertamente por los costumbristas. Por ello, a principios del año 2004, el obispo dispuso la creación de una Comisión integrada por tres sacerdotes de la diócesis de Tuxtla, tres miembros de la Mayordomía zoque y tres miembros de la parroquia de Copoya, entre ellos el presidente de la Junta de Festejos. Se plantearon como tareas principales de esta comisión: custodiar a las imágenes durante el tiempo que peregrinan a Tuxtla, además de asesorar y dar visto bueno a todo lo relativo a los festejos, precisar los criterios y evitar aquello que debilite o sea contrario a la vida cristiana, entre otras cosas. Sin embargo, dicha propuesta fue rechazada por las asociaciones zoques, porque para sus miembros era 
una propuesta unilateral debido a que no había sido consensada entre las partes en conflicto.

Con la "reubicación" de las celebraciones de las Vírgenes de Copoya se busca implementar los criterios de la Iglesia para evitar todo aquello que debilite o fuera contrario a las disposiciones que marca el dogma católico. El objetivo de esta campaña evangelizadora tiene como principal interés que:

Impulse la verdadera devoción y amor a la Santísima Virgen, se rescaten y fortalezcan las buenas tradiciones y costumbres zoques en torno a esta devoción; no se pierda nada de lo bueno, se articule más esta devoción en relación con lo que es fundamental a la fe católica: La pastoral profética, la pastoral litúrgica, la pastoral social y la Comunión eclesial (Diócesis Tuxtla, 2004: s/p).

El proyecto evangelizador implementado trata de promover, fortalecer y rescatar "las buenas tradiciones zoques" con el fin de guardarlas sanas. La Iglesia establece una estrategia aplicable a los grupos de "catolicismo popular" de la ciudad de Tuxtla Gutiérrez, dirigida principalmente a la Mayordomía.

Parte de este proyecto diocesano probablemente tiene su origen en las modificaciones conceptuales en términos misionales que surgieron a partir del Concilio Vaticano Segundo (1963-1965) "en el cual se definieron las políticas misioneras, se planteó precisamente que la evangelización se debía darse en los términos de la cultura propia de los pueblos evangelizados" (Masferrer, 2000:32); y en otros pronunciamientos como la exhortación católica Evangelii Nutiandi de Pablo VI (1975); la "Opción de los Pobres" a la que convocaron las conferencias episcopales de Medellín (1968) y Puebla (1979); y de la encíclica "Redentoris Missio" de Juan Pablo II (1990), para combatir el "catolicismo popular" (Báez-Jorge, 2000). Aunado a esto no debemos olvidarque no es hasta el año 1965 que Tuxtla Gutiérrez se constituye en obispado y con ello su diócesis - ésta abarca el noroeste de la Depresión de Central, las Montañas Zoques, y las Llanuras de Pichucalco-,${ }^{16}$ lo que hizo necesario la creación de un proyecto evangelizador propio, acorde a la población que atendería y las dinámicas sociales que se presentaban en estas tres regiones.

La campaña actual de catequización surge del proyecto general del nuevo obispo asignado a Tuxtla, monseñor Chávez Botello. No debemos olvidar que aunque están supeditados al proyecto general de la iglesia católica, los prelados tienen la libertad de implementar algunas acciones en sus diócesis con el fin de lograr los objetivos de evangelización que se plantea la institución católica. Estas adecuaciones en la mayoría de los casos son transmitidas al grupo de párrocos y sacerdotes de la diócesis en cuestión, mismos que a su vez comienzan a trabajar bajo esos lineamientos entre las agrupaciones de laicos a su cargo. Por ejemplo, para el caso de Tuxtla Gutiérrez la Iglesia ha trabajado con los grupos de apostolados integrados por las Comunidades Cristianas y las Pastorales.

Sin embargo, entre los mismos clérigos se han encontrado discrepancias. Algunos sacerdotes se inclinan por la evangelización gradual —enculturación-, la cual debería de considerar elementos del "catolicismo popular" para generar un cambio en la devoción de los feligreses. Otros, en cambio, se encuentran en una postura impositiva para lograr su objetivo. Esta última es la que genera conflictos religiosos.

\section{Estrategias de evangelización: Tuxtla Gutiérrez}

Respecto a la estrategia de evangelización de los grupos populares, se constituyó desde la época de monseñor Aguirre Franco — década de los años 90- una Cofradía conformada principalmente por laicos que tenían conocimiento de las tradiciones zoques. La organización debía seguir las directrices planteadas por 
el proyecto diocesano de ese entonces. Esta nueva agrupación católica quedó insertada en un sector de la Iglesia denominado "Grupos de religiosidad popular".

\section{La Cofradía de San Marcos}

Un ejemplo palpable de lo anterior es la asociación religiosa Cofradía de San Marcos, formada por un grupo de personas "disidentes" de la Mayordomía del Rosario, aspecto que se ve reflejado en sus patrones religiosos, normados en parte por la dirección de la nueva evangelización promovida por la diócesis y también por el conocimiento ritual de "el Costumbre".

Los miembros de esta Cofradía se separaron de la Mayordomía del Rosario en los años 90 del siglo pasado, debido a que algunos de sus miembros no fueron tomados en cuenta para ocupar cargos de importancia dentro de la organización. ${ }^{17}$ Éste fue el caso del señor Rosemberg Juárez, quien pensaba que al fallecer don Francisco Velázquez, Albacea de la Mayordomía, sería electo para ocupar el cargo, situación que no fue bien recibida por los componentes de dicha asociación. En la votación realizada para elegir nuevo Albacea fue designado don Paulino Jonapá Alejo.

En los últimos años, los miembros de la Cofradía de San Marcos han argumentado que algunas de las prácticas rituales que se realizan en la Mayordomía del Rosario están alejadas del sentido que marca "el Costumbre". En cambio, la Cofradía de San Marcos reclama ser la asociación religiosa zoque que reproduce los rituales tal como mandan los cánones de "el Costumbre".

Al mismo tiempo, el sacerdote encargado de la Catedral de San Marcos era el padre Oscar Juárez. Los miembros de la Mayordomía afirman que durante sus gestiones como responsable de la Catedral apoyó la fundación de la Cofradía, contando para ello con la anuencia del obispo Aguirre Franco y del representante del ayuntamiento local, que en ese momento era de extracción panista —Enoch Araujo Sánchez-. Este elemento puede ayudar a entender por qué la Cofradía de San Marcos, durante el período de Aguirre Franco y Enoch Araujo, cobró gran relevancia, llegando a organizar por primera vez en 1998 la fiesta del santo patrón San Marcos a la manera "tradicional". La Cofradía estaba incluida dentro del Patronato de la Feria, por eso le asignaron recursos para los eventos. Quien dirigía las actividades de los festejos al santo patrón de la ciudad era el Albacea de la Cofradía de San Marcos, Rosemberg Juárez, padre a su vez del sacerdote Oscar Juárez. Además estaban otros principales como Francisco Velázquez, hijo del anterior Albacea de la Mayordomía del Rosario.

En la actualidad, debido al conflicto, el sacerdote Oscar Juárez ha sido designado directamente por el obispo como uno de los miembros de la Comisión Eclesiástica que tiene como objeto evaluar el desarrollo de las celebraciones zoques, con el argumento de que no hay nadie más ad hoc para esta actividad que el padre Oscar, por ser descendiente directo de una familia zoque tuxtleca conocedora de "el Costumbre".

La Cofradía de San Marcos ha reproducido algunos símbolos y prácticas heredados, mismos que se han resignificado con la intención de cambiar su concepción sobre las imágenes religiosas y su culto. Además esta agrupación ha tratado de suprimir los altos niveles de gasto económico aplicados a los insumos de velas, flores, cohetes y alimentos, también pone especial énfasis en la prohibición de la ingesta de bebidas alcohólicas, aspecto último que la Iglesia, en múltiples ocasiones, ha señalado como uno de los principales puntos que deshumaniza y desvirtúa a la devoción. En los últimos años la asociación, al parecer, se encuentra sumida en una crisis, ya que debido a la falta de nuevos miembros los cargos se rotan entre las mismas personas, lo que provoca una especie de "endogamia" en la organización de cargos. Esta situación origina en sus miembros un desgaste emocional y principalmente 
económico, por los pagos que contrae un "carguero" al recibir un puesto.

\section{La Pastoral Juvenil}

Está conformada por un grupo de personas encargadas de desarrollar otra estrategia de evangelización que va dirigida a los jóvenes de la localidad de Copoya con la intención de inculcar en las nuevas generaciones algunas prácticas religiosas que son bien vistas por la Iglesia. Como en el caso anterior, esta estrategia de catequización busca modificar las tradiciones zoques.

En la actualidad, la parroquia de Copoya tiene bajo su cargo a la pastoral juvenil, ${ }^{18}$ grupo que está conformado por varias Comunidades Cristianas de Jóvenes de esta población. Dentro de sus actividades se contemplan: la oración, asistir a misa los domingos, asistir a retiros de crecimiento y retiros de espiritualidad, también en sus reuniones semanales proponen algunos temas que tienen que ver con "Iglesia y Sociedad". En estas reuniones se transmiten a los jóvenes ideas sobre la "correcta" aplicación y desempeño de la fe cristiana en la vida cotidiana.

Los planteamientos adquiridos en las reuniones son transmitidos entre sus redes de parentesco, generándose, principalmente, desavenencias en algunas familias por considerar estas ideas como un perjuicio contra "el Costumbre" que practican algunos adultos y ancianos en Copoya. Este aspecto es un elemento muy importante dentro de las estrategias de evangelización, ya que a través de él se busca romper las antiguas estructuras, minar las añejas concepciones devocionales y las prácticas tradicionales. Asuntos que son considerados por la Iglesia como elementos que impiden la aplicación y el desarrollo de la "verdadera" esencia de la fe cristiana en los devotos. En resumen, éste es un mecanismo que a largo plazo busca modificar los esquemas operativos de la praxis de la religión y la fe de los costumbristas.

\section{Discursos y estrategias contrapuestos}

En este conflicto se recurre a una serie de discursos que tratan de avalar las nociones que cada grupo tiene sobre el culto a las imágenes, sin embargo, hasta el momento, se han identificado dos versiones. La primera es una explicación utilizada por algunos defensores de la tradición, como los costumbristas, ésta se encuentra fuertemente vinculada a un complejo de lo sagrado estructurado por el mito, la leyenda, el culto, la devoción, los vínculos de parentesco consanguíneo - alianzas-, y por la fiesta, recreándose de esta manera la historia del grupo; la segunda, se basa en los preceptos oficiales marcados por la iglesia católica.

\section{La Mayordomía del Rosario y la Junta de Festejos de Copoya}

Ambas asociaciones religiosas dan un valor importante a elementos como la concepción de los espacios geográficos, el tiempo, y algunos contemplan una forma de vida anterior; relacionados con las actividades del campo por haber sido principalmente un pueblo agrícola. En algunas ocasiones se argumenta que este grupo de hombres y mujeres son herederos y continuadores de las tradiciones de los indios zoques - primigenios pobladores de Tuxtla - por lo que han seguido reproduciendo ceremonias y rituales como: la Robadera, la Siembra, la danza del nast-etzé - baile de la tierra-, la Santa Cruz, entre otras, donde se recrea de manera particular el mundo. Los mencionados elementos coadyuvan a la construcción de una identidad comunitaria, reafirmándose la relación entre las imágenes, la población, y su territorio, ${ }^{19}$ de ahí que el templo de Copoya, y en general el pueblo, sea concebido como un espacio geográfico que durante muchos años ha sido el coto de resguardo de una de las devociones religiosas más antiguas de los zoques de Tuxtla. 
Por ejemplo, el complejo de lo sagrado hace que las personas sigan asignándole a la música, la danza, la indumentaria ritual, la gastronomía, las procesiones, y a algunos símbolos como el Joyonaqué (Flor-amarrada), el Joyo Soc Toc (Chocolatillo), el Somé (Enrames) ofrenda a las imágenes, confeccionada a partir de hojas de algunas plantas y flores, a la cual se le agregan comestibles como panes, dulces o frutos-, las imágenes religiosas, el V indacoy — rezo para dar el cargo a un Prioste o Mayordomo-, los cantos "de Pastores", los diferentes estados de ánimo que se dan en torno a la fiesta - chistes con doble sentido, cuentos, apodos-, las concepciones de existencia, las conversaciones diarias, su memoria histórica; un carácter esencial en sus creencias rituales y religiosas. Espacios naturales como la tierra, ojos de agua, pozos o cuevas, por ejemplo la "cueva del Ramillete", y los cerros, principalmente el Mactumatzá; han sido concebidos como lugares en donde habitan seres poderosos, que lo mismo influyen en las lluvias, pues propician y aseguran las buenas cosechas, o protegen al pueblo de las enfermedades.

\section{La Iglesia}

En segundo lugar, se presenta un discurso que corresponde al grupo de prodiocesanos en donde toda la explicación de la veneración se argumenta en relación con los preceptos oficiales de la Iglesia, derivados de argumentos teológicos y hagiográficos de la vida de los santos, y exegéticos en términos de una hermenéutica religiosa al interpretar el mensaje de la divinidad. De ahí que en este segundo discurso no se perciba una relación con referentes míticos, leyendas o rituales, como se presenta en los costumbristas. Por lo tanto, el discurso manejado por los prodicesanos genera un sentimiento de cohesión entre sus miembros apegado a un dogma, factor que interviene en la construcción de una identidad diferente a la del otro grupo.

\section{Tres medios de defensa de "el Costumbre"}

Se ha tenido la idea durante mucho tiempo que los pueblos zoques de Chiapas fueron grupos indígenas pasivos, que aceptaron la imposición de sistemas económicos, jurídicos, sociales, religiosos, sin aspavientos; en síntesis, que fueron actores indiferentes de su historia. Sin embargo esto no es así, por lo menos para el caso que nos atañe, el de los zoques de Tuxtla. Sabemos por algunos documentos históricos que los miembros de este grupo social han sido sujetos activos de su historia y que han actuado en consecuencia cuando han visto amenazadas sus formas de organización religiosa y económica, principalmente..$^{20}$

La manera en cómo han reaccionado la Mayordomía del Rosario y la Junta de Festejos de Copoya debido a la representación cúltica y de integración devocional implementada por la diócesis no es nueva, sin embargo, tiene un aspecto muy particular, ya que en el afán de proteger la tradición, en estos tiempos "modernos", los miembros de dichas agrupaciones religiosas han recurrido a varias estrategias entre las que podríamos destacar la defensa jurídica, la difusión en los medios de comunicación y el financiamiento económico, con el fin de establecer un mecanismo sólido para la defensa de "el Costumbre". Lo anterior demuestra cómo las nuevas generaciones de jóvenes costumbristas, entre los que se encuentran arquitectos, ingenieros, abogados, comerciantes, entre otros, formados en escuelas técnicas y universidades públicas o privadas, aplican sus conocimientos y actúan como intermediarios ante instituciones oficiales o privadas.

\section{Apoyo institucional y jurídico}

La nueva generación de costumbristas, avalados por los Principales de mayor edad, se ha dedicado a buscar apoyo de instituciones en donde pueda canalizar su 
problema. Por ejemplo, pidió ayuda a la Subsecretaría de Asuntos Religiosos del Gobierno del Estado, para que fungiera como mediadora entre las partes en conflicto.

Por otro parte, ha demandado el apoyo de una organización no gubernamental en materia de derechos humanos para sustentar a través de la ley su lucha. Como resultado del respaldo brindado por este organismo, las agrupaciones religiosas zoques de Copoya y Tuxtla se han conformado como asociación civil, denominada "Asociación para la Conservación de las Costumbres Religiosas Zoques de Tuxtla y Copoya, A. C." En el mes de abril de 2004, el abogado de esta asociación realizó algunas gestiones urgentes en la Ciudad de México, ante la Secretaría de Gobernación y de Relaciones Exteriores, con la intención de iniciar los trámites correspondientes para presentar a esta agrupación como una asociación religiosa. Las gestiones en este sentido continúan.

El objetivo central de la asociación es preservar "el Costumbre", además de abogar por su reconocimiento como legítima heredera de las tradiciones zoques. Esta condición — consideran los costumbristas — los avala para que se les garantice:

...el derecho de los pueblos y de las comunidades indígenas a la libre determinación y, en consecuencia, a la autonomía para:

I. decidir sus formas internas de convivencia y organización social, económica, política y cultural.

II. aplicar sus propios sistemas normativos en la regulación y solución de sus conflictos internos, sujetándose a los principios generales de esta Constitución...

III. preservar y enriquecer sus lenguas, conocimientos y todos los elementos que constituyan su cultura e identidad.

[Ya que en] el artículo 24 de la Constitución federal se establece: la libertad de todo hombre "para profesar la creencia religiosa que más le agrade y para practicar las ceremonias, devociones o actos del culto respectivo, siempre que no constituyan un delito o falta penados por la ley", congruente con el artículo $2^{\circ}$ de la ley de Asociaciones Religiosas y Culto Público" (Asociación Civil, Tuxtla, 2004: s/p).

Lo anterior se acordó con la finalidad de conseguir en primera instancia una representatividad jurídica ante otras instituciones — gubernamentales y eclesiásticas- que pudieran intervenir en el conflicto, pero principalmente para que se respeten sus usos y costumbres.

Por otro lado, como parte de esta contienda, se están buscando los procedimientos legales para que el templo de Copoya sea nuevamente entregado a la Asociación Civil para la Conservación de las Costumbres Religiosas Zoques de Tuxtla y Copoya, además de su administración y custodia, como históricamente ha sido, ya que al quedar constituidas ambas agrupaciones como una asociación religiosa, ésta puede solicitar al gobierno federal el cuidado del santuario. Las gestiones aún no han concluido.

\section{La difusión del conflicto}

En lo que corresponde a la difusión de este conflicto religioso, los representantes legales de la asociación civil han pedido que la disputa sea cubierta permanentemente por algunos medios locales de comunicación, como los periódicos La Voz del Sureste, Diario de Chiapas, El Cuarto Poder, el Heraldo de Chiapas; la radio y la televisión - TV Azteca Chiapas, Noticinco, Canal 10- Conociendo el funcionamiento e impacto que provocan los medios masivos de comunicación en la sociedad, organizaron una rueda de prensa con el objetivo de detallar su postura ante este conflicto religioso y dar a conocer el planteamiento de la Iglesia respecto a las manifestaciones devocionales y de celebración a las Vírgenes de Copoya. Esta acción 
llevada a cabo por las agrupaciones zoques no fue bien recibida por la Iglesia, ya que la institución esperaba que el problema se manejara únicamente entre las dos instancias, situación que se vio alterada cuando los representantes de las asociaciones zoques mostraron a la luz pública la disputa en que se encontraban, provocando una fragmentación en algunos sectores de la sociedad tuxtleca. Surgieron así los grupos que apoyan a los prodiocesanos o a los costumbristas.

\section{El financiamiento}

La organización de cargos de los zoques de Tuxtla está constituida por una serie de puestos que se alternan entre los miembros de las asociaciones religiosas zoques a que pertenecen. Éstos asumen el cargo por un periodo que va de uno a tres años. Los cargos se establecen jerárquicamente. En las agrupaciones zoques de Tuxtla se emplean tres diferentes maneras para acceder a los cargos: por asignación, por solicitud o por rotación.

Los puestos para custodiar y celebrar a las imágenes están vinculados con la devoción y recursos económicos con que cuenten las personas. Por regla general las asociaciones religiosas populares de Tuxtla Gutiérrez ponen un lapso que va de uno a tres años para que los cargueros desempeñen sus funciones (López, 2003:7). Como podemos ver existe un protocolo ritual que ordena las designaciones de los puestos en las agrupaciones zoques. Este mecanismo hace difícil que los costumbristas puedan ofrecer al mejor postor la posesión temporal de algún cargo, tal como argumenta la Iglesia.

El capital acumulado por los Priostes, Mayordomos o Socios a lo largo del año se destina a la compra de insumos para la fiesta. Algunos materiales se almacenan, por ejemplo las velas y el incienso. Otros elementos rituales como pollos o cerdos vivos se compran y se crían con anticipación, también se adquieren no perecederos: maíz, cacao, azúcar, licor y algunas especies. Podemos afirmar que los Priostes o Mayordomos en parejas de hombre y mujer —, requieren cantidades de dinero que van de los $\$ 15000.00$ a $\$ 60000.00$ pesos, según sea la jerarquía de la imagen que custodian para cumplir con "el Costumbre". Esto significa que la pareja de cargueros realiza un gasto que va de $400 \mathrm{a}$ 1600 salarios mínimos actuales, durante su año de gestión (López, 2003:7). ${ }^{21}$

Además del sistema de ahorro que emplean los Priostes o Mayordomos para cumplir con "el Costumbre", se auxilian, en menor medida, con el capital que se obtiene de la caja colectiva. ${ }^{22}$ La cual se conforma con las limosnas que se recogen durante las celebraciones religiosas que organiza la agrupación costumbrista. El dinero acumulado es entregado por el grupo de Albaceas, en presencia de los Priostes y Mayordomos, al nuevo carguero junto con una serie de bienes materiales -floreros, sahumerios, camarines, ropa de la imagen, entre otros — - El capital recaudado es utilizado por el carguero para abastecer de insumos a la fiesta. El Principal que recibe este beneficio tiene el compromiso, al término de sus gestiones, de reintegrarlo junto con una suma extra. ${ }^{23} \mathrm{Al}$ interior de la Mayordomía se genera un capital que sirve periódicamente para subsanar los gastos que generan los rituales. ${ }^{24} \mathrm{El}$ monto acumulado a través de las cajas colectivas no es abundante, $y$, por ende, no permite que los principales especulen y se enriquezcan con él.

Sin embargo, el dinero que se llega a conseguir durante los dos meses del año en que las vírgenes de Copoya permanecen en la ciudad de Tuxtla Gutiérrez, durante el periodo de "Las Pedidas", es una suma importante, pues se llega a acumular hasta $\$ 30000.00$ pesos por año. Los costumbristas afirman que el dinero que se obtiene de los devotos de las "Copoyitas" es empleado en el acondicionamiento del santuario donde quedan las tres imágenes, pero, principalmente, en su construcción. Este último aspecto es lo que, según los 
costumbristas, ha motivado a la Iglesia a implementar una campaña de represión cúltica contra "el Costumbre", con el objetivo de apropiarse de la devoción y, principalmente, del capital que genera esta celebración católica popular.

Como vemos, los gastos que tienen que realizar los miembros de estas agrupaciones son muchos, por ello existen mecanismos financieros que ayudan al Principal a cumplir con su cargo. Si sumamos los gastos ordinarios que hace un carguero durante un año de gestión, a los que ha generado extraoficialmente el conflicto religioso en este año a la Mayordomía y Junta de Festejos de Copoya - por concepto de representación jurídica-, se puede entender que las agrupaciones zoques han hecho un esfuerzo añadido para saldar este compromiso.

El grupo de costumbristas ha innovado e implementado nuevos mecanismos de cooperación. El primero funciona al interior de la Mayordomía y Junta de Festejos de Copoya y dispone que cada miembro tenga el compromiso moral y económico de cubrir una cuota de dinero determinada para reunir una cantidad común que será destinada a cubrir parte de los gastos generados en pro de "el Costumbre". El segundo opera al exterior del grupo y tiene el objetivo de buscar financiamiento, empleando las relaciones comerciales que tienen establecidas algunos de sus miembros con empresas de importancia en el ámbito nacional.

Estas dos formas de financiamiento hasta el momento han dado buenos resultados, pues les ha permitido saldar importes deudas: pago de abogado, boletos de avión, réditos sobre dinero prestado, papelería, entre otros requerimientos. La defensa de "el Costumbre" requiere de nuevas estrategias y dinámicas colectivas, hecho que han sabido aprovechar los costumbristas al recurrir a organismos legales, medios de comunicación, nuevos mecanismos de cooperación y financiamiento, para mantener vigentes sus concepciones y prácticas religiosas a pesar de la represión en el culto y de la integración devocional que mantiene la iglesia local en contra de ellas.

Lo anterior muestra que en el afán de imponer el dogma católico a las celebraciones populares zoques, la Iglesia ha generado una serie de diferencias entre algunos de los pobladores de Copoya. Estas desavenencias han producido rivalidades entre los prodiocesanos y los costumbristas que han venido a complicar más las dinámicas cotidianas de la localidad. El conflicto religioso ha llegado a tal nivel de violencia que cualquier acción de una u otra parte puede provocar sucesos como el del enfrentamiento del 27 de abril de 2004, si no de mayores proporciones.

\section{Conclusiones}

\section{Los desencuentros entre la Mayordomía y el proyecto evangelizador}

Si hacemos un balance del proyecto evangelizador nos damos cuenta que la empresa catequizadora no se ha logrado, al contrario, ha generado un conflicto religioso, ya que en el afán de imponer su proyecto universalista en la prédica de la "Buena nueva", tal vez con toda buena intención, la Iglesia ha comenzado a realizar una serie de descalificaciones y acciones en contra del otro sistema religioso con el objetivo de modificar la concepción y las prácticas de veneración de este grupo. Como es el tema de la devoción a la Virgen. En este sentido, el obispo Chávez Botello, basándose en el dogma, precisa que las tres imágenes de Copoya:

...no se refieren a tres Vírgenes, son tres representaciones de la misma Virgen María en su advocación de Ntra. Señora de la Candelaria, Ntra. Señora de la Asunción y Ntra. Señora del Rosario. Los diferentes nombres que damos a la Madre de Dios nos recuerda los variados misterios, bondades y títulos con que el pueblo cristiano, en diferentes épocas 
y lugares, experimenta cercano el amor y la protección de la Santísima Virgen; nos hablan también de las abundantes gracias con que Dios dotó a María Santísima. (Diócesis Tuxtla, 2004: s/p).

Aquí debemos de hacer un par de anotaciones. En primer lugar, los costumbristas conciben de manera distinta a las Vírgenes de Copoya. Algunos reconocen que las tres imágenes se refieren a tres advocaciones diferentes de la Virgen; otros, incluidos algunos ancianos, sin embargo las perciben como deidades separadas. Inclusive existen personas que guardan una devoción particular por una de las tres imágenes, a la cual le piden favores y hacen mandas para que les conceda milagros.

A cada una de estas Vírgenes le son conferidas diferentes características. Por ejemplo, Candelaria se relaciona con la propiciación de la tierra y las lluvias, de ahí que se festeje durante los primeros meses del año, antes del periodo de lluvias. La Virgen del Rosario es poseedora de una fuerte significación agrícola vinculada con el período de cosecha, de ahí que se conmemore en el mes de octubre, época en que también se realizan

las primeras tareas relacionadas con la recolección del maíz. Por otro lado, refiriéndonos a la Virgen de la Asunción, aunque la Mayordomía y la Junta de Festejos no tienen bajo su resguardo esa imagen sí custodian y veneran a una tercera Virgen, pero es la de María Olachea, ${ }^{25}$ celebrada en el mes de octubre, el día de Santa Teresita del Niño Jesús —-Teresa de Lisieux-, por ser esta su advocación. El festejo de esta Virgen se enlaza con el periodo de cosechas, al igual que los festejos de la Virgen del Rosario.

La Iglesia no se ha percatado de que cambiar la lógica a la devoción popular de las "Copoyitas" es una empresa difícil y compleja, debido a que la celebración se encuentra vinculada a un sistema de creencias que se produce en un campo constituido por la organización familiar, vecinal, grupal y, también, por el trabajo agrícola que se realizaba años atrás. De ahí que cada celebración religiosa popular zoque se establezca en determinados tiempos y espacios: ya sea en el santuario de Copoya, en la ermita del Cerrito, en el cerro del Zanate, en la cueva del Ramillete, en la casa del Prioste, en la casa del Mayordomo; antes de las lluvias, durante la época de lluvias, previo a la recolección de la cosecha [...] Es decir, "el Costumbre" ${ }^{26}$ zoque se concibe de manera interdependiente con el ciclo agrícola. ${ }^{27}$

Los miembros de las asociaciones zoques consideran que durante $300 \operatorname{años}^{28}$ la tradición ha estipulado que las Vírgenes de Copoya sean llevadas en una procesión a la ciudad de Tuxtla, dos veces al año: del 30 de enero hasta finales de marzo, y del 14 al 23 de octubre. ${ }^{29}$ Para este grupo la modificación de las fechas en que se celebra a las Vírgenes de Copoya es un hecho que en el fondo busca hacer de "el Costumbre" un mero objeto mercantil. Se argumenta que la Iglesia de Tuxtla busca controlar y administrar esta devoción porque considera que en torno a estas tres imágenes se producen considerables ingresos monetarios. La institución cree que los Principales de las asociaciones zoques comercian con las imágenes, de ahí que los costumbristas consideren que la Iglesia pone gran énfasis en su lucha para lograr el control y la administración de los símbolos de la tradición.

\section{Notas}

${ }^{1}$ Robledo, Antonio, "De Copoya y sin clonar", en Cuarto Poder, viernes 15 de octubre de 2004. p. B13. Sobre el lado sur de la ciudad de Tuxtla Gutiérrez, existe una localidad llamada Copoya (Agencia Municipal agregada al municipio de Tuxtla). De los orígenes de ésta la antropóloga Dolores Aramoni nos dice que dicho lugar era una hacienda de ganado vacuno en donde existía una pequeña capilla dedicada a Nuestra Señora del Rosario, propiedad del común de los indios zoques de Tuxtla. Esta estancia se fue poblando poco a poco con los naturales zoques que iban siendo despojados de sus propiedades urbanas, por ello, éstos fueron migrando hacia la hacienda de Copoya, de tal manera que el 3 de octubre de 1892, siendo gobernador de 
Chiapas Emilio Rabasa, se erigió por decreto en pueblo de la congregación de familias establecidas en la antigua hacienda de la Virgen del Rosario (Aramoni, 1992).

${ }^{2}$ Los términos "Subida" y "Bajada" obedecen a que la localidad de Copoya se encuentra en un lugar más elevado — m.s.n.m.- que la ciudad de Tuxtla Gutiérrez, la cual está asentada sobre un valle.

${ }^{3} \mathrm{El}$ grupo de prodiocesanos está conformado por jóvenes "copoyeros" que participan en el grupo de pastoral juvenil, así apoyan el movimiento orquestado por el clero regular. Esta posición activa en la estructura católica los relaciona de manera directa con la Iglesia, el párroco y, por ende, son considerados por los costumbristas como el mecanismo principal que emplea el clero para poner en marcha el proyecto diocesano de evangelización.

${ }^{4}$ Los costumbristas son los vecinos organizados en torno a la Mayordomía del Rosario y a la Junta de Festejos de Copoya que tiene bajo su custodia a varias imágenes religiosas, entre ellas a las Vírgenes de Copoya.

${ }^{5}$ Ubicada en calle Palma Viajera 203, colonia Las Palmas, norte oriente de Tuxtla Gutiérrez

${ }^{6}$ La descripción de los eventos del 27 de abril de 2004 se basa en conversaciones informales sostenidas con algunos miembros de la Mayordomía del Rosario, pero principalmente, de uno de sus ramilleteros, el señor Armando Ovilla, miembro activo de esta organización, quien fue uno de los retenidos en el enfrentamiento. Agradezco enormemente la confianza, el tiempo y las atenciones prestadas, para obtener esta información.

${ }^{7}$ Debemos señalar que el 21 de abril los representantes de la Mayordomía sostuvieron una reunión con una comisión integrada por siete sacerdotes, entre los que se encontraba el sacerdote Severo. En esta junta acordaron los representantes de la Iglesia no actuar en contra de las tradiciones religiosas zoques. ${ }^{8}$ Lo que hay que destacar de este día, es que los contingentes que llegaron a apoyar a los prodiocesanos provenían tanto de la parroquia de Copoya, como de otras parroquias de localidades y municipios cercanos, como el Jobo, Terán, Suchiapa, San Cristóbal e Ixtapa. Hay quienes afirman que también participaron algunos miembros de la OCEZ (Organización Campesina Emiliano Zapata).

${ }^{9}$ El Albacea es un cargo de la Mayordomía que se encarga de supervisar que las celebraciones religiosas que realizan los costumbristas en Tuxtla Gutiérrez se apeguen a "el Costumbre". El puesto de don Paulino es el cargo de mayor autoridad dentro de la Mayordomía, está por encima del Presidente de la Junta de Festejos y de los Priostes y Mayordomos.

${ }^{10}$ Especialista ritual que tiene como tarea la elaboración de ofrendas florales, que se otorgan tanto a las imágenes de la Mayordomía como a los Principales que pasarán a formar parte de la organización de cargos de estas asociaciones religiosas (Mayordomía del Rosario-Junta de Festejos de Copoya).

${ }^{11}$ Comunicación directa de don Julio Aquino Tondopo, Tuxtla Gutiérrez, julio de 1998.

${ }^{12}$ Cf. Los refugios de lo sagrado. Religiosidad, conflicto y resistencia entre los zoques de Chiapas. Dolores Aramoni Calderón. Consejo Nacional para la Cultura y las Artes, México, 1992.

${ }^{13}$ Según la antropóloga Dolores Aramoni, "En los últimos años, la jerarquía eclesiástica no ha visto con buenos ojos esta manifestación desbordante de religiosidad, por lo que acusa a los celebrantes de borrachos y de faltar el respeto a las imágenes, cosa inexacta según nos consta, ya que el orden en el cuarto-altar en que son colocadas es estrictamente vigilado, aunque afuera se bebe, se fuma y se baila sin restricción. Consideramos que lo que resulta molesto a la jerarquía eclesiástica es el estar excluida de esta celebración" (Aramoni, 1992: 403-404).

${ }^{14}$ Comunicación directa de Martín Sol, Copoya 3 de mayo de 2004.

${ }^{15}$ Esta celebración consiste en que algunas familias devotas de las Vírgenes de la ciudad de Tuxtla piden, con anticipación, a la Mayordomía del Rosario y Junta de Festejos de Copoya que las imágenes sean llevadas a su casa, para que durante todo un día sean veneradas por la familia y los vecinos del barrio o colonia. Dentro de sus obligaciones, la Pedidora o el Pedidor deben organizar la fiesta en general. Los procuradores no tienen una participación permanente en la organización de cargos de la Mayordomía o Junta de Festejos zoques.

${ }^{16}$ Hasta 1957 la diócesis de Chiapas (jurisdicción) coincidía con el estado de Chiapas; éste se dividió en tres obispados: San Cristóbal de Las Casas: parte suroriental de la Depresión Central de los Llanos de Comitán, las Montañas Mayas, la Selva Lacandona y las Llanuras de Palenque. Soconusco: Llanura costera del Pacífico, la vertiente sur de la Sierra Madre y la región de Motozintla (región Sierra). Y Tuxtla Gutiérrez (Viqueira, 2002:127).

${ }^{17}$ Cf. López, 2001, para conocer más datos sobre la conformación jerárquica de esta agrupación. 
${ }^{18}$ Antes del 2 febrero de 2004, el templo de Copoya dependía de la parroquia de San Francisco, ubicada en la ciudad de Tuxtla Gutiérrez, sobre la $1^{\mathrm{a}}$ calle poniente, entre la 14 y 15 avenida sur. ${ }_{19}$ Algo semejante ocurre en muchas otras áreas rurales de mesoamérica. Por ejemplo para los q'eqchíes Richard Wilson propone... "una distinción conceptual entre la identidad comunitaria, con una existencia histórica más prolongada en el área y estrechamente vinculada con el espacio geográfico y las formas de vida campesina, y la identidad étnica, reciente difusa y contextual, fundada en criterios lingüísticos, aquellos que usan gobierno, iglesias, antropólogos y representantes de organizaciones indígenas". Para entender este argumento es necesario revisar algunos aspectos del trabajo etnográfico del autor. Wilson propone que el culto a los truultaq'as (dueños o espíritus de las montañas y dueños originales del maíz) ha sido el centro de la identidad comunitaria en los pueblos agrícolas del área q'eqchí cuya base de subsistencia es la producción de la milpa para el autoabasto. Los trunltaq'as fueron entidades vinculadas al territorio inmediato, a los recursos fundamentales, al ciclo agrícola y a la salud; y los ritos agrícolas, en particular las peregrinaciones a lugares sagrados estaban ligadas a la subsistencia cotidiana. Todas estas prácticas implican una reafirmación permanente de la estrecha relación entre la población y su territorio..." (Escalona, 2003: 139- 140: refiriéndose al texto de Wilson: Resurgimiento Maya en Guatemala. —experiencia q'eqchi'es_: 1999).

${ }^{20}$ Cf. "Juan de Oliver, primer Alcalde mayor de Tuxtla", Dolores Aramoni Calderón, Universidad Autónoma de Chiapas, 1985. "Motines y cambios en las formas de control económico y político: los eventos de Tuxtla en 1693”. Murdo J. Macleod. 1995.

${ }^{21}$ Datos obtenidos en febrero de 2003. El cálculo de los salarios mínimos se realizó de acuerdo con los $\$ 37.00$ pesos vigentes en Chiapas, en el año de 2003.

${ }^{22}$ Es muy probable que la actual caja colectiva de la Mayordomía del Rosario sea una derivación de las cajas comunales que existían en la época colonial, las cuales fueron instauradas con el objetivo de fortalecer el sistema tributario colonial, los fondos se conformaban con el ingreso de las utilidades colectivas y las subvenciones que se utilizaban de garantía para el pago del tributo y la satisfacción de necesidades de asistencia social.
${ }^{23}$ Por ejemplo, en el año 2002 al carguero del Santísimo Sacramento saliente le fue entregada inicialmente la cantidad de $\$ 1000.00$ pesos, al dejar el puesto entregó la cantidad de \$1 150.00 pesos.

${ }^{24}$ En la época colonial los festejos “alrededor de los santos, no sólo de las cofradías de indios, sino también de las de españoles, incluían comilonas y excesos en la bebida... los gastos para tales celebraciones incluían, además, los de la cera y pago de servicios al cura... habría que agregar los que se hacían en fuegos artificiales..." (Aramoni, 1995:15), recurriendo para ello al capital acumulado por el devoto que organizaba la fiesta a la imagen, en otras ocasiones se empleaba parte de capital común para sufragar estos gastos.

${ }^{25}$ Sin embargo, su iconografía nos remite a la representación de la Virgen del Rosario.

${ }^{26}$ Término que designa a todo el conjunto de la tradición y que a su vez regula las prácticas del grupo.

${ }^{27}$ En estas nuevas circunstancias, como es el espacio heterogéneo en el que se ha convertido la ciudad de Tuxtla, la religiosidad zoque es reelaborada constantemente con nuevos referentes para ajustarse a los nuevos tiempos y exigencias de la urbe en donde se desarrolla.

${ }^{28}$ Sobre el origen de la "Bajada de las Vírgenes" de Copoya, no se tienen datos precisos. Sin embargo, en 1852, los indios zoques habían solicitado la intervención del gobernador del estado ante la diócesis para que el obispo concediera la licencia para bendecir la nueva ermita que ahí se había construido, y poder así celebrar misas. El permiso fue negado después de ser consultado el vicario José de Vila... El padre José Vila informó también al obispo que se había enterado, por medio de la Priosta María Cundoqui y otros indígenas, que no era el pueblo el que solicitaba la habilitación de la ermita, sino el gobernador indio Prudencio Fonseca y otros principales, cuyo interés era que ese año se celebrara la fiesta de la Virgen en la ranchería de Copoya, disposición ésta que tanto la Priosta como otros indígenas no estaban dispuestos a cumplir, ya que según el cura: '...si a la Señora la bajan, como es costumbre, desde luego están de llano a pagármela...' (Citado en Aramoni, 1992: 397). Nótese la afirmación hecha por el cura en el siglo XIX 'como es costumbre', esto nos da indicios para asentar la idea de que la fiesta de las "Copoyitas", no es una celebración nueva. 
${ }^{29}$ Cf. Etnografía de las Mayordomías de Tuxtla. Omar López Espinosa. Tesis de Licenciatura en Antropología Social, Facultad de Ciencias Sociales Campus III, San Cristóbal de Las Casas, Chiapas; 2001.

\section{Bibliografía}

Aramoni Calderón, Dolores, 1985, “Juan de Oliver, primer alcalde mayor de Tuxtla", en revista UNACH I, Universidad Autónoma de Chiapas, Tuxtla Gutiérrez. pp. 46-62.

—, 1992, Los refugios de lo sagrado. Religiosidad, conflicto y resistencia entre los zoques de Chiapas. Consejo Nacional para la Cultura y las Artes. México.

—, 1995, "Indios y Cofradías. Los zoques de Tuxtla", en Anuario V, Instituto de Estudios Indígenas - Universidad Autónoma de Chiapas. Tuxtla Gutiérrez. pp. 13-26.

Báez-Jorge, Felix, 2000, "Cinco siglos de intolerancia (de la satanización de los dioses mesoamericanos a la persecución de las devociones populares)", en La Palabra y el Hombre, núm. 115. Julio-Septiembre. Universidad Veracruzana, Xalapa, Veracruz.pp. 7-23.

Escalona Victoria, José Luis, 2003, Reseña, Wilson Richard, 1999 Resurgimiento maya en Guatemala (experiencia q'eqchi' es), Centro de Investigaciones Regionales de MesoaméricaPlumsock Mesoamerican Studies, CIRMA/PMS, Guatemala, serie monografía núm. 10, en Liminar, Año I, Vol. I, núm. 1, junio. Centro de Estudios Superiores de México y Centroamérica. Universidad de Ciencias y Artes de Chiapas. Tuxtla Gutiérrez, Chiapas. pp. 139-142.

González M, José Luis, 2001, "El catolicismo y las Culturas Populares en México", en Antología. Diplomado de Gestión Cultural - CONACULTA - México. ms. pp: 2-21.

López Espinosa, Omar, 2001, Etnografía de las Mayordomías de Tuxtla. Tesis de Licenciatura en Antropología Social. Facultad de Ciencias Sociales. Campus III. Universidad Autónoma de Chiapas. San Cristóbal de Las Casas, Chiapas.

—, 2003, Mequé güicúy y mequé ujсuy. Tiempo, espacio y orden en la gastronomía ritual zoque. Tuxtla Gutiérrez, Chiapas. ms. pp. 1-27.

Masferrer Kan, Elio, 2000, "La configuración del campo religioso latinoamericano el caso de México", en Sectas o Iglesias. Viejas y Nuevas Religiones. Asociación Latinoamericana para el Estudio de las Religiones_-Plaza y Valdés. pp. 19-83. México.

Macleod, Murdo J., 1995, "Motines y cambios en las formas de control económico y político: los acontecimientos de Tuxtla 1693", en Chiapas: Los Rumbos de otra Historia. Viqueira Juan Pedro y Mario Humberto Ruz (editores). Centro de Estudios Mayas del Instituto de Investigaciones Filológicas y Coordinación de Humanidades (UnAM). Centro de Investigaciones y Estudios Superiores en Antropología Social, Centro de Estudios Mexicanos y Centroamericanos, Universidad de Guadalajara. México. pp. 87-102.

Víqueira, Juan Pedro, 2002, "Existos y Fracasos de la evangelización en Chiapas (1545-1859)", en Encrucijadas Chiapanecas. Economia Religión e Identidades. Tusquest-El Colegio de México. México.

\section{Documentos}

Diócesis de Tuxtla Gutiérrez, A.R. circular 1/04. Enero 5 de 2004. Tuxtla Gutiérrez, Chiapas.

Representantes de la "Asociación para la Conservación de las Costumbres Zoques de Tuxtla y Copoya A. C.", documento enviado a la Secretaría de Gobernación a la Dirección General de Asociaciones Religiosas, 25 de marzo de 2004. Tuxtla Gutiérrez, Chiapas

Sánchez, Abenamar, "Rompen Zoques con la Iglesia", en Diario la Voz del Sureste. 29 de marzo de 2004. pp. 3 y 36. Tuxtla Gutiérrez, Chiapas.

Domínguez Nuñez, Carlos, "Peligra la Tradición Zoque", en Diario de Chiapas. 29 de Marzo de 2004, pg. 75. Tuxtla Gutiérrez, Chiapas.

Hernández Aguilar, Jorge Enrique, “Cuidado con los usos y costumbres, caso Copoya. ¡Pasiones Religiosas!”, en Diario de Chiapas. 31 de marzo de 2004. Pg. 39. Tuxtla Gutiérrez, Chiapas. "Las Virgencitas de Copoya. Una tradición que la Iglesia quiere conservar", Editorial, en Semanario Católico. 18 de abril de 2004, pg. s/n. Tuxtla Gutiérrez, Chiapas.

Sibaja, Perla , "Sigue conflicto por Vírgenes de Copoya", en Diario Cuarto Poder. 4 de mayo de 2004, pg. B2. Tuxtla Gutiérrez, Chiapas.

Valencia, Valeria, "Cultura zoque más viva que nunca", en Diario ElHeraldo de Chiapas. 12 de mayo de 2004, pg. 4c. Tuxtla Gutiérrez, Chiapas. 